\section{Timber, Tetrameles nudiflora R., resistant to Teredid Borers in Bombay Harbour}

THE destruction by wood-borers of timbers used for marine construction has been a serious problem in both temperate and tropical waters. This communication directs attention to the resistance of the timber Tetrameles nudiflora to attack by marine boring organisms. This is interesting in view of the fact that this timber has been graded as coming under class III in respect of durability on land as assessed in grave-yard trials ${ }^{1}$.

Untreated panels of $T$. nudiflora (12 in. $\times 3$ in. $\times 0.5$ in.) were immersed in the sea at three widely separated sites in Bombay Harbour. Sixteen panels were immersed at each site together with an equal number of Abies pindrow (Himalayan fir) panels which served as controls. Damaged controls were replaced normally after every 3 months.

The exposures were carried out from July 1962 to September 1965. There were four separate exposures (Table 1).

Table 1

$\begin{array}{ll}\text { Exposure I: from } 9-7-62 \text { to } 21-8-63: & 14 \text { months } \\ \text { Exposure II: from } 9-7-62 \text { to } 20-3-64: & 20 \text { months } \\ \text { Exposure III: from } 20-3-64 \text { to } 17-10-64: & 7 \text { months } \\ \text { Exposure IV: from } 20-3-64 \text { to } 1-9-65: & 18 \text { months }\end{array}$

The samples exposed to attack were examined at intervals of 3 months by sectioning to determine the extent of internal deterioration. The control panels were examined in a similar manner.

The teredid borers reported ${ }^{2}$ from Bombay waters are Bankia (Bankiella) carinata G., B. (Liliobankia)-companellata M.R., Teredo (Kuphus) manni W., T. (Bactronophorus) thoracites G., and T. (Teredo) elongata Q. The
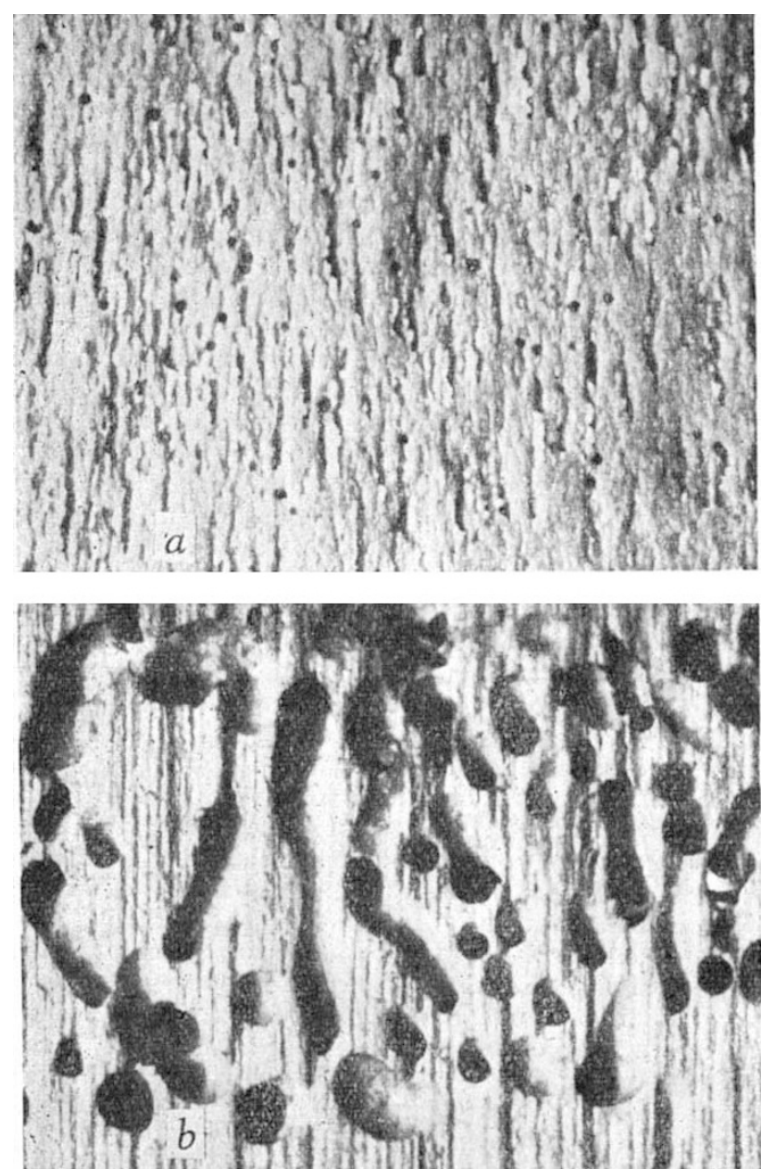

Fig. 1. Teredo attack under laboratory conditions. $a$, Surface view of the test piece of Tetrameles nudiflora; $b$, cruss-section of the control
Abies pindrow. ( $\times 3$. presence of $T$. furcifera, a synonym of $T$. parksi, and also Lyrodus pedicellatus has recently been observed by us. The incidence of the last two Teredo borers and $B$. companellata at the sites of exposure for the past 4 years has been very heavy.

Periodical examination of the test panels revealed that none of these was damaged by the teredid worms, Teredo and Bankia, at any time during their exposure. At one of the sites (Trombay) some panels did show attack of Martesia sp., but this was not surprising as this pholad is well known for its catholic preference. The control timber panels were heavily attacked and damaged by all types of borers within about 3 months of exposure.

Microscopic examination of the exposed test panels revealed the presence of innumerable entry holes or larval pits of $0.25 \mathrm{~mm}$ diameter, with the dead remains (chitinous shells) of the veliger larvae. It was therefore evident that although there had been initial anchorage or attack, there had been no progress in burrowing and the larvae had died. On almost all occasions, the larvae suffered death before their chitinous shells were transformed into calcareous ones. The superficial attack of the larvae did not impair the strength of the timber panels tested.

With a view to confirming the field exposure results described previously, the laboratory exposures of this timber were also made. The larvae of $T$. furcifera were used as the test organisms, as recommended by Becker ${ }^{2}$. This borer ${ }^{3}$ has been found to be a very convenient test organism for the experimental work. Small pieces of $T$. nudiflora were offered for the attack of the teredid larvae. The timber pieces of Abies pindrow (Himalayan fir) were used as controls. Figs, $1 a$ and $b$ illustrate the damage suffered by $T$. nudiflora and $A$. pindrow. The results obtained in the laboratory tanks were similar to those obtained on the raft trials in the open sea.

I thank Shri S. K. Ranganathan and Shri C. P. De for their advice and encouragement.

\section{A. A. KaRANDE}

Naval Chemical and Metallurgical Laboratory, Naval Dockyard,

Bombay 1.

1 Anon, Indian Standard (IS), 401, I (1954).

${ }^{2}$ Becker, G., F.A.O. Report No. 795, Rome (1958).

${ }^{3}$ Karande, A. A., Science and Culture, 32 (7), 380 (1966).

\section{New Type of Nuclear Life Cycle in Hemileia vastatrix}

Hemileia vastatrix ${ }^{1}$ is the cause of rust disease of coffee, and there have been many investigations of its life cycle. This rust is characterized by the formation of non-resting tcliospores which germinate in situ and produce sporidia, which, however, are unable to reinfect coffee, which suggests that they are non-functional ${ }^{2-4}$. Pycnial and aecial stages of this rust are not known. We have conducted further investigations of the life cycle of and mode of perennation of this fungus, with special emphasis on nuclear behaviour.

Fresh leaf material in various stages of infection was fixed in Carnoy's fluid for $1 \mathrm{~h}$, then kept in 'Craf' A and B for $24 \mathrm{~h}$, washed, dehydrated and embedded in paraffin wax according to the usual procedure. Sections $10 \mu$ thick were cut. Nuclei were stained with iron haematoxylin, crystal violet, and Foulgen. Temporary mounts were made in acetocarmine.

The results obtained show that the parasitic hyphae are dikaryotic ( $A$ and $B$ in Fig. 1 ) in the initial stages, and later become diploid and monokaryotic through fusion of the dikaryons $(C)$. This nuclear status is maintained in the stromatal hyphae, the sporogenous hyphae as well as the spore mother cells $(D$ and $F$ ). The single diploid nucleus in the spore initials divides mitotically 